\title{
PERANAN KEBERHASILAN PENERAPAN SOFTWARE AKUNTANSI MELALUI KUALITAS SISTEM INFORMASI, KUALITAS INFORMASI DAN PERCEIVED USEFULNESS
}

\author{
Praptiningsih $^{1)^{*}}$, Satria Yudhia Wijaya ${ }^{2)}$, Fitri Yetty ${ }^{3)}$ \\ ${ }^{1}$ Fakultas Ekonomi Dan Bisnis, Universitas Pembangunan Nasional Veteran Jakarta \\ email: praptiningsih@upnvj.ac.id \\ ${ }^{2}$ Fakultas Ekonomi Dan Bisnis, Universitas Pembangunan Nasional Veteran Jakarta \\ email: satria.wijaya@gmail.com \\ ${ }^{3}$ Fakultas Ekonomi Dan Bisnis, Universitas Pembangunan Nasional Veteran Jakarta \\ email: fitriyetty 61@yahoo.com
}

\begin{abstract}
The process of implementing accounting software means how an accounting software can facilitate user performance to produce quality information and help information users in making decisions. Companies can measure the success of accounting software implementation with respect to the quality of information systems, information quality, and perceived usefulness that are closely related to users of accounting software. Based on this, this study aims to analyze the success of accounting software through the variables of Information System Quality, Information Quality and Perceived Usefulness. The population in this study are bank employees who work in South Jakarta. The sample in this study uses accidental sampling aimed at bank employees who use information systems in 2021. Hypothesis testing in this study uses Multiple Regression Analysis with the SPSS program. The results of hypothesis testing show variables, and partially have a significant effect on the Successful Role of Accounting Software Implementation. The results of hypothesis testing show that (1) Information System Quality has a significant effect on the Successful Role of Accounting Software Implementation (2) Information Quality has a significant effect on the Successful Role of Accounting Software Implementation (3) Perceived Usefulness has a significant effect on the Successful Role of Accounting Software Implementation
\end{abstract}

Keywords: Accounting Software; System Quality; Information; Perceived Usefulness

\begin{abstract}
ABSTRAK
Proses implementasi perangkat lunak akuntansi berarti bagaimana suatu perangkat lunak akuntansi dapat memfasilitasi kinerja pengguna untuk menghasilkan informasi yang berkualitas dan membantu pengguna informasi dalam pengambilan keputusan. Perusahaan dapat mengukur keberhasilan implementasi perangkat lunak akuntansi berkenaan dengan kualitas sistem informasi, kualitas informasi, dan kegunaan yang dirasakan sangat terkait dengan pengguna perangkat lunak akuntansi. Berdasarkan hal tersebut, penelitian ini bertujuan untuk mengalisis peneranan keberhasilan software akuntansi melalui variabel Kualitas Sistem Informasi , Kualitas Informasi dan Perceived Usefulness. Populasi dalam penelitian adalah pegawai bank yang bekerja di Jakarta Selatan. Sampel dalam penelitian ini menggunakan sampling aksidental ditujukan kepada pegawai bank yang menggunakan sistem informasi pada tahun 2021. Pengujian hipotesis dalam penelitian ini menggunakan Analisis Regresi Berganda dengan program SPSS. Hasil pengujian hipotesis menunjukan variabel , dan secara parsial berpengaruh signifikan terhadap Peranan Keberhasilan Penerapan Software akuntansi. Hasil pengujian hipotesis menunjukan bahwa (1) Kualitas Sistem Informasi berpengaruh signifikan terhadap Peranan Keberhasilan Penerapan Software akuntansi (2) Kualitas Informasi berpengaruh signifikan terhadap Peranan Keberhasilan Penerapan Software akuntansi (3) Perceived Usefulness berpengaruh signifikan terhadap Peranan Keberhasilan Penerapan Software akuntansi
\end{abstract}

Kata Kunci: Software Akuntansi; Kualitas Sistem; Informasi; Perceived Usefulness

\footnotetext{
*Corresponding author. E-mail: praptiningsih@upnvj.ac.id
} 


\section{PENDAHULAN}

Seiring berkembangnya teknologi informasi saat ini, software akuntansi dapat dibuat sesuai dengan kebutuhan perusahaan. Hal ini memberikan nilai kepuasan tersendiri bagi para pemakainya. Software akuntansi yang dibuat sesuai dengan standar akuntansi di suatu negara akan menghasilkan pengolahan data akuntansi yang baik dan informasi yang berkualitas. Hal tersebut menjadikan proses implementasi software akuntansi memerlukan adanya pembelajaran dan penyesuaian, agar software akuntansi dapat berhasil diimplementasikan sesuai dengan standar akuntansi yang berlaku.

Kemajuan teknologi ini disebut sebagai gangguan digital, yaitu mengaburkan perbedaan antara bidang fisik, digital, dan biologis. Tingkat gangguan digital yang meningkat, misalnya muncul kecerdasan buatan, tidak hanya mengubah tata kelola bisnis dan teknologi inovatif, tetapi juga memengaruhi pengambilan keputusan sebagai peluang binis. Selain itu ganggunag digital juga memberikan tekanan bagi suatu organisasi untuk mengadopsi sebuah teknologi dengan tujuan untuk meningkatkan produktivitas dan keuntungan mereka. Banyak teknologi baru yang mulai melakukan tugas yang secara tradisional dilakukan oleh akuntan, misalnya penggunaan software akuntansi tertentu. Dimana hal ini diprediksi akan terus mengurangi ketergantungan bisnis pada akuntan (Demirkan dkk., 2020; Love dkk., 2020; Marrone \& Hazelton, 2019)

SI memiliki fungsi yang penting untuk menyediakan layanan yang baik dan keunggulan bersaing. Namun demikian, kegagalan pada SI menjadi isu utama bagi organisasi. Sektor industri perbankan mengalami dinamika pembangunan yang paling cepat terkait teknologi sistem informasi. Maka industri perbankan diharuskan tanggap pada perubahan yang terjadi karena adanya persaingan yang ketat antara perbankan, baik ditingkat lokal maupun internasional (Syah dkk., 2019). Bakhit (2017) menyatakan investasi pada SI memiliki pengaruh terhadap industri perbankan. Kegalalan tersebut menyebabkan biaya dan waktu yang berlebih, dan tidak tercapainya tujuan dan sasaran strategis.

Bank BCA pernah mengalami kegagalan yang terjadi pada salah satu produknya yaitu M-BCA pada tahun 2020. Nasabah tidak bisa mengakses dikarenakan lampu indikator yang terus berwarna merah, sedangkan untuk bisa melakukan transaksi lampu inidikator harus berwarna hijau (Laucereno, 2020). Dari permasalah di atas, dapat dikatakan bahwa SI dari ketiga bank tersebut tidak berhasil. Merujuk dari penelitian yang dilakukan Petter dkk (2008) mengatakan bahwa dari sudut pandang teknologi, model kesuksesan SI mengusulkan dua dimensi kualitas, kualitas sistem salah satunya. Kualitas sistem merupakan karakteristik dari teknologi itu sendiri, yang berfokus pada aspek kegunaan seperti kemudahan penggunaan, efisiensi, dan reabilitas atau keandalan.

Dengan menggunakan suatu aplikasi atau sistem, pengguna merasakan bahwa kinerja, efektivitas, dan produktivitas mereka lebih meningkat (Khan \& Chaipooirutana, 2020) Ketika melihat kembali peristiwa di atas, dapat disimpulkan bahwa nasabah tidak merasakan manfaat yang seharusnya mereka rasakan ketika menggunakan suatu sistem

Pada akhirnya ketika membicarakan SI tidak akan terlepas dari kepuasan pengguna akhir sistem. Menurut Hall (2007) pengguna akhir didefinisikan sebagai setiap orang yang menggunakan sistem yang dibangun. Kepuasan pengguna merujuk pada sejauh mana pengguna percaya bahwa SI mampu memenuhi informasi yang mereka butuhkan (Guangbin \& Jiule, 2016). Kepuasan pengguna juga merupakan bagian dari efektivitas sistem. Di mana sistem dikatakan efektif jika out put yang 
dihasilkan lebih besar dari target yang dicapai (Andarwati dkk., 2020). Hal ini mengindikasikan bahwa tidak hanya persepsi kegunaan saja, tetapi kualitas sistem dan kualitas informasi mejadi faktor yang menentukan kepuasaan pengguna SI

Salah satu cara untuk mengukur kualitas sistem informasi adalah dengan mengetahui seberapa cepat sistem (software akuntansi ) tersebut dapat mengolah data akuntansi yang masuk menjadi sebuah laporan keuangan. Hal ini tentunya juga dibantu oleh kemampuan pemakai SIA tersebut, semakin mudah pengoperasiannya maka semakin cepat proses pengolahan datanya sehingga menjadi laporan keuangan yang baik. Tujuan dalam penelitian ini untuk menganalisis pengaruh Kualitas Sistem Informasi , Kualitas Informasi dan Perceived Usefulness terhadap keberhasilan penerapan software akuntansi.

Berdasarkan dari uraian diatas maka penelitian yang akan dilakukan memiliki perumusan masalah yaitu apakah kualitas sistem informasi, kualitas informasi dan Perceived Usefulness berpengaruh signifikan terhadap Peranan Keberhasilan Penerapan Software akuntansi. Tujuan dari penelitian ini untuk menguji kualitas sistem informasi, kualitas informasi dan Perceived Usefulness berpengaruh signifikan terhadap Peranan Keberhasilan Penerapan Software akuntansi. Penelitian ini menggabungkan variabel dari beberapa peneliti sebelumnya, sampel yang digunakan dalam penelitian ini berbeda dengan acuan dasar dalam penelitian sebelumnya yaitu responden pegawai bank yang terlibat langsung dalam penggunakaan software akuntansi pada tahun 2021.

\section{KAJIAN LITERATUR}

Teori Keberterimaan Teknologi atau lebih terkenal dengan sebutan The Technology Acceptance Model (TAM) adalah model yang paling banyak dan umum digunakan dan sudah tervalidasi dalam menjelaskan keyakinan, sikap, niat, dan perilaku yang berkaitan dengan aplikasi teknologi informasi (Mostafa, 2020). Pada TAM niat perilaku dipengaruhi oleh sikap pengguna terhadap suatu produk atau teknologi baru, sikap ini pada akhirnya dipengaruhi oleh persepsi keguanaan dan persepsi kemudahan penggunaan (Koenig-Lewis dkk., 2015)

Dalam teori ini menyebutkan bahwa persepsi kegunaan (perceived usefulness) merupakan bentuk harapan dari pengguna bahwa ketika mereka menggunakan suatu aplikasi atau sistem, maka kinerja mereka akan meningkat. Berikutnya yaitu persepsi kemudahan penggunaan (perceived ease of use) sebagai bentuk harapan dari pengguna bahwa ketika mereka menggunakan suatu aplikasi atau sistem, maka mereka tidak perlu melakukan banyak usaha untuk mengoperasikannya. Dua dimensi tersebut inilah yang merupakan kunci utama dalam penerimaan suatu teknologi (Köck, 2017, hlm.1-3). TAM sendiri telah menjadi sebuah model yang paling diterima mengenai penerimaan dan penggunaan suatu teknologi karena dalam berbagai studi empiris, model TAM muncul dalam literatur mengenai SI sebagai teori yang paling banyak digunakan untuk menyelidiki tentang pemakaian sistem (Isaac dkk., 2018). Ketika pengguna mudah dalam menerima SI, hal ini merupakan sinyal bahwa mereka merasakan manfaat menggunakan SI dalam menyelesaikan tugas. Selain itu, persepsi kemudahan penggunaan yang merupakan variabel independen secara signifikan memengaruhi persepsi kegunaan, dimana persespsi kegunaan menjadi komponen penting dalam kepuasan pengguna SI (Andarwati dkk., 2020), (Gumussoy dkk., 2018) . 


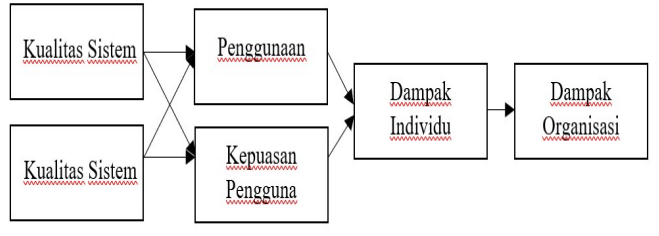

Sumber: DeLone \& McLean (1992)

Gambar 1. Model Keberhasilan SI Delone \& McLean (1992)

Setelah menerima berbagai usulan, pada DeLone dan McLean (2003) memperbarui ISSM 1992 dengan menambahkan 'niat untuk menggunakan' sebagai alternatif untuk penggunaan jika diperlukan, 'kualitas layanan' merupakan dimensi baru yang memiliki pengaruh pada penggunaan dan kepuasan pengguna, dan 'manfaat bersih' untuk mengganti variabel dampak individu dan dampak organisasi. Dengan perbaikan ini, memungkinkan model untuk diimplementasikan oleh peneliti ke tingkat kajian apapun yang relevan.

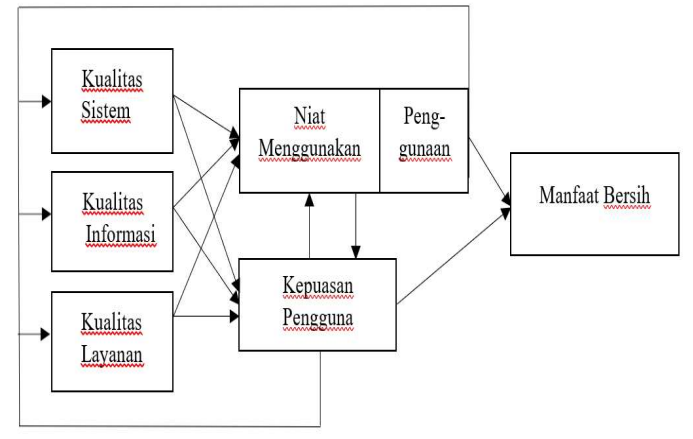

Sumber: Delone \& McLean (2003)

Gambar 2. Model Keberhasilan SI

Delone \& McLean (2003)

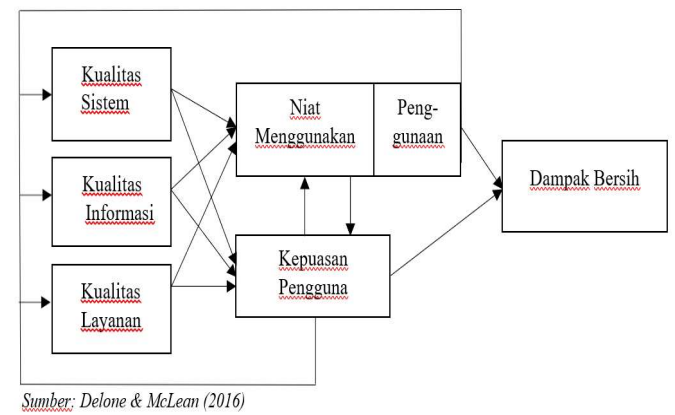

DeLone \& McLean (2016) melakukan perubahan pada dimensi 'manfaat bersih'. Perubahan ini dikarenakan 'manfaat' hanya menyiratkan hasil yang positif, sedangkan DeLone \& McLean meginginkan agar model ini mengenali hasil yang positif dan negatif bisa terjadi. Perubahan inilah yang selanjutnya mengembangkan proses siklus hidup sistem. Ketika digambarkan secara grafis, panah umpan balik ditampilkan mulai dari 'penggunaan' dan ''kepuasan pengguna' lalu kembali ke 'kualitas sistem', 'kualitas informasi', dan 'kualitas layanan'

Kepuasan pengguna didefinisikan sebagai tanggapan pengguna atas output yang dihasilkan oleh suatu sistem (Delone \& McLean, 1992) Sedangkan menurut Almazán dkk (2017) kepuasan pengguna diartikan sebagai bagaimana perasaan pengguna setelah menggunakan suatu sistem (keyakinan), jika mereka menggapnya sudah efisien, efektif, dan sesuai dengan kebutuhan mereka. Keyakinan akan kebutuhan mereka menjadi tolak ukur peranan keberhasilan penerapan software akuntansi. Ada 8 pernyataan untuk mengukur keberhasilannya, mencakup sistem memberikan informasi yang dibutuhkan,informasi yang dibutuhkan tepat, , program akurat, sistem dipahami dengan jelas,user friendly, tepat waktu, dan up to date.

DeLone \& McLean (2016) menjelaskan kualitas sistem yang diinginkan memiliki karakter seperti mudah digunakan, mudah dipelajari, fleksibel, dan andal. Seddon (1997) mengatakan kualitas sistem berkaitan apakah terdapat kerusakan dalam sistem, konsistensi antarmuka pengguna, kemudahan penggunaan, kualitas dokumentansi, dan pemeliharaan kode program. Ada 8 perntaaan untuk mengukur kualitas sistem informasi yaitu mampu meningkatkan kapasitas pemrosesan, sistem memiliki keamanan, memiliki fasilitas menkoreksi pada software akuntansi, sistem menuat informasi, mudah dalam penggunaannya, mudah dipelajari, dan kecepatan akses 
Kulitas informasi merupakan output dari sistem. Kualitas informasi yang dinginkan memiliki karakter seperti relevan, mudah dipahami, disajikan secara ringkas tetapi tetap lengkap, bersifat akurat, dan tepat waktu ketika dibutuhkan (DeLone \& McLean, 2016). Kualitas informasi seperti laporan administrasi, perlu memiliki karakteristik yang jelas, sesuai, dan berguna (Petter dkk., 2008). Ada 6 pernyataan mencakup sistem bersifat akurat, dapat dipercaya, tepat waktu,relevan,mudah dipahami, bersifat detail dan benar

Perceived Usefulness didefinisikan sebagai rasa percaya atas penggunaan teknologi. Kegunaan yang dirasakan berkaitan dengan sejauh mana sistem informasi dapat membantu dalam meningkatkan kinerja dan kualitas efisiensi dalam pekerjaan pengguna (Davis, 1989). Sejalan dengan Davis, Fadlan \& Dewantara, (2018) menyebutkan persepsi kemanfaatan sebagai mampu tidaknya seorang pengguna diwaktu mendatang secara subjektif menggunakan teknologi informasi yang secara spesifik dapat meningkatkan kinerja pekerjaan. Ada 5 pernyataan untuk mengukurnya mencakup sistem membantu lebih cepat, meningkatkan kineja, meningkatkab produktivitas, meningkatkan efektifitas,dan mudah menyelesaikan pekerjaan.

\section{METODE PENELITIAN}

Populasi studi ini mencakup pegawai bank yang terlibat langsung menggunakan software akuntansi di Jakarta Selatan. pengambilan sampel, peneliti menggunakan sampling aksidental. Dalam Payadnya \& Jayantika (2018, hlm.25) bahwa teknik ini mengambil sampel secara kebetulan, maksudnya siapapun yang yang secara tidak sengaja bertemu dengan peneliti dan memenuhi kriteria yang dibutuhkan, akan dijadikan sampel. Dalam penelitian ini, peneliti akan mendatangi kantor cabang (KC) atau kantor cabang pembantu (KCP) bank-bank konvensional yang ada di Jakarta. Bank konvensional yang dipilih ialah bank yang masuk dalam kategori khada IV (modal inti paling sedikit tiga puluh triliun rupiah) yaitu BRI, BCA, Bank Mandiri, BNI, Bank Panin, CIMB Niaga, Bank Danamon, dan Bank Permata (Khadafi, 2021). Sampel yang digunakan ialah teller, customer service dan finance yang menggunakan software akuntansi.

Penelitian ini menggunakan skala likert $1 \mathrm{~s} / \mathrm{d} 5$ untuk mengukur seluruh variabel. Dengan skor 1 sangat tidak setuju, skor 2 tidak setuju, skor 3 kurang setuju, skor 4 setuju, dan skor 5 sangat setuju.

Pengujian hipotesis menggunakan analisis regresi linear berganda. Dalam hal ini, pengujian terhadap peranan keberhasilan penerapan software akuntansi yang bisa mempengaruhi variabel yang akan diteliti yaitu kualitas sistem informasi, kualitas informasi dan Perceived Usefulness. Analisis regresi ini mempunyai persamaan yakni:

$$
\mathrm{Y}=\alpha+\beta \mathrm{X} 1+\beta \mathrm{X} 2+\beta \mathrm{X} 3+e
$$

Dimana Y adalah peranan keberhasilan penerapan software akuntansi, X1 adalah kualitas sistem informasi, X2 adalah kualitas informasi, X3 adalah Perceived Usefulness, $\beta_{0}$ adalah bilangan konstanta, $\beta_{1-4}$ adalah Koefisien regresi dan $\varepsilon$ adalah error.

\section{HASIL DAN PEMBAHASAN}

Peranan keberhasilan penerapan software akuntansi melalui kualitas sistem informasi, kualitas informasi, dan perceived usefulness telah dilakukan penyebaran kuisioner ke 100 responden . Telah disusun kerangka pikir guna memperlancar diselesaikannnya permasalahan pada hal yang diteliti ini, didasari oleh penjelasan diatas. Berikut adalah bentuk kerangka model penelitian: 


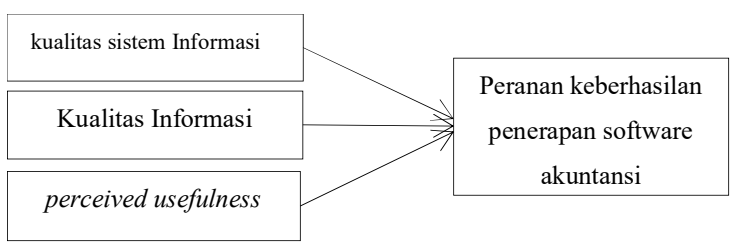

Gambar 1. Kerangka Model Penelitian

Hasil analisis deskriptif di setiap variabel penelitian diperoleh dengan memanfaatkan program SPSS 25 for windows. Penyebaran kuisioner dari 100 responden diperoleh pengembalian sebesar 81 sampel, sisanya 19 tidak mengembalikan kuisioner .

Tabel 1. Hasil Statistik Deskriptif

\begin{tabular}{lccccc}
\hline \multicolumn{7}{c}{ Statistik Deskriptif } \\
\hline & N & Min & Maks & Rerata & SD \\
\hline Sistem & 81 & 24 & 38 & 36,63 & .38 \\
Informasi & 81 & 28 & 40 & 27,02 & .33 \\
Usefulness & 81 & 20 & 25 & 22,79 & 35 \\
Software & 81 & 27 & 40 & 36,89 & .04 \\
akuntansi & & & & & \\
Valid N & 81 & & & & \\
(listwise) & & & & &
\end{tabular}

Sumber: Hasil SPSS

Tabel 1 menunjukkan analisis deskriptif pada masing-masing variabel penelitian dapat dijelaskan bahwa rata-rata semua responden menjawab setuju dan sangat setuju untuk variable yang diteliti .Hal ini menunjukkan responden memahami pentingnya peranan keberhasilan penerapan software akuntansi sangat diperlukan dakam pekerjaan mereka. Uji validitas dibawah 0,00 dibawah 0,5 yang artinya semua pertanyataan valid dan hasi uji reabilitas terpenuhi hasilnya 0,84 lebih besar dari nilai Cronbach's Alpha 0,70 yang artinya kuisioner bersifat reabel atau konsisten.

Uji normalitas memakai uji statistik Kolmogorof-Smirnov mempertimbangkan hasil dari nilai residual yang tidak terstandarisasi. Tabel berikut memperlihatkan hasil estimasi uji normalitas sudah terpenuhi.

Tabel 2. Hasil Uji Statistik KolmogrovSmirnov

\begin{tabular}{llr}
\hline & \multicolumn{1}{c}{$\begin{array}{c}\text { Unstandardized } \\
\text { Residual }\end{array}$} \\
\hline $\mathrm{N}$ & Mean & 81 \\
Normal & Std. & .0000000 \\
Parameters ${ }^{\mathrm{a}, \mathrm{b}}$ & Deviation & 1.0657780 \\
& Absolute & .070 \\
Most Extreme & Positive & .070 \\
Differences & Negative & -.047 \\
Test Statistic & .070 \\
Asymp. Sig. (2-tailed) & $.200^{\mathrm{c}, \mathrm{d}}$ \\
\hline a. Test distribution is Normal. \\
\hline b. Calculated from data. \\
\hline c. Lilliefors Significance Correction. \\
\hline d. This is a lower bound of the true significance. \\
\hline
\end{tabular}

Uji multikolonieritas melihat keberadaan hubungan antar variabel bebas di model regresi. Uji multikolonieritas dalam studi ini memakai Variance Inflation Factors (VIF) dan tolerance. Hasil memperlihatkan nilai VIF setiap variabel bebas $>10$. Nilai tolerance setiap variabel bebas memperlihatkan seluruhnya bernilai $>0,1$. Maka, tidak ada hubungan multikolinieritas pada variabel bebas di model regresi tersebut.

Tabel 3. Hasil Uji Multikolonieritas

\begin{tabular}{llll}
\hline \multicolumn{4}{c}{ Coefficients $^{\mathbf{a}}$} \\
\hline & \multicolumn{3}{c}{$\begin{array}{c}\text { Collinearity } \\
\text { Statistics }\end{array}$} \\
\hline & Model & Tolerance & VIF \\
\hline \multirow{3}{*}{1} & (constant) & & \\
& sisteml & .780 & 1.480 \\
& Informasi & .751 & 1.813 \\
& Usefulness & .927 & 1.079
\end{tabular}

a. Dependent Variable: Software akuntansi

Untuk memperkuat hasil uji tersebut, maka dilakukan pengujian heteroskedastisitas menggunakan uji glejser. Tabel 4 memperlihatkan nilai sig pada variabel kualitas sistem informasi 0,341, kualitas informasi 0,479 , jumlah perceived usefulness 0,755 , dan software akuntansi 0,637 yang melebihi nilai $\alpha$ 0,05 . Dengan demikian, tidak terjadi heterokedastisitas di model regresi sehingga model regresi ini pantas digunakan dalam analisa selanjutnya.

Tabel 4. Hasil Uji Glejser 


\begin{tabular}{clccc}
\hline & Model & & $\mathrm{t}$ & Sig. \\
\hline \multirow{3}{*}{1} & (Constant) & & 1.925 & .431 \\
& sisteml & & .958 & .341 \\
& Informasi & & .712 & .479 \\
& Usefulness & & -.310 & .755
\end{tabular}

a. Variabel Terikat: Software akuntansi

Uji ini melihat adanya hubungan antara kesalahan penganggu di 1 periode terhadap kesalahan pengganggu di periode yang lebih awal di model regresi. Untuk menguji autokorelasi, uji Durbin Watson (D-W) umum dilakukan. Hasil analisis memakai program SPSS 25 ditunjukkan di Tabel 4:

Tabel 5. Hasil Uji Autokorelasi

\begin{tabular}{ll}
\hline \multicolumn{2}{c}{ Model Summary $^{\mathbf{b}}$} \\
\hline \multicolumn{1}{c}{ Model } & D-W \\
\hline 1 & .728 \\
\hline $\begin{array}{l}\text { a. Predictors: Opini audit, belanja modal, SKPD, } \\
\text { aset }\end{array}$ \\
\hline b. Variabel Terikat: Pengungkapan LKPD \\
\hline
\end{tabular}

Tabel 4 memperlihatkan nilai DW = 0,728 yang berada di -2 hingga +2 . Sehingga, tidak terdapat autokorelasi dalam model ini.

Analisis ini mengetes pengaruh dari 2 variabel bebas atau lebih terhadap 1 variabel terikat. Hasil analisis memakai program SPSS 25 terlihat di tabel beriktu:

Tabel 6. Hasil Model Regresi

\begin{tabular}{|c|c|c|c|c|}
\hline \multicolumn{5}{|c|}{ Coefficients $^{\mathrm{a}}$} \\
\hline & \multirow{2}{*}{ Model } & \multicolumn{2}{|c|}{$\begin{array}{c}\text { Unstandardized } \\
\text { Coefficients }\end{array}$} & \multirow{2}{*}{$\begin{array}{c}\begin{array}{c}\text { Standardized } \\
\text { Coefficients }\end{array} \\
\text { Beta }\end{array}$} \\
\hline & & B & $\begin{array}{l}\text { Std. } \\
\text { Error }\end{array}$ & \\
\hline \multirow{4}{*}{1} & (Constant) & 8.687 & 2.677 & \\
\hline & sistem & .366 & .154 & .267 \\
\hline & Informasi & .345 & .122 & .329 \\
\hline & Usefulness & .322 & .113 & .297 \\
\hline
\end{tabular}

Tabel 6 memperlihatkan nilai koefisien regresi dan konstanta untuk bisa dibuat menjadi persamaan regresi linear di bawah ini:

\section{Software $=8,687+0,366$ sistem $+0,345$ \\ Informasi $+0,322$ Usefulness}

Uji ini melihat sejauh mana variabilitas variabel bebas mampu memperjelas variabilitas variabel terikat nilai koefisien determinasi adalah 0,645 yang memperlihatkan kualitas sistem, kualitas informasi dan perceived usefulness mempengaruhi sebesar 64,5\% terhadap peranan keberhasilan penerapan software akuntansi. Sedangkan sisanya $35,5 \%$ merupakan pengaruh dari faktor lain di luar penelitian ini.

Tabel 7. Hasil Koefisien Determinasi

\begin{tabular}{ccccc}
\hline \multicolumn{4}{c}{ Model Summary } \\
\hline Model & $\mathrm{R}$ & $\begin{array}{c}\mathrm{R} \\
\text { Square }\end{array}$ & $\begin{array}{c}\text { Adjusted } \\
\mathrm{R} \\
\text { Square }\end{array}$ & $\begin{array}{c}\text { Std. Error of } \\
\text { the Estimate }\end{array}$ \\
\hline 1 & $.832^{\mathrm{a}}$ & .725 & .645 & 1.54123 \\
\hline $\begin{array}{l}\text { a. Predictors: (Constant), sistem, informasi, } \\
\text { usefulness, software akuntansi }\end{array}$ \\
\hline
\end{tabular}

Uji t melihat apakah koefisien variabel kualitas sistem, kualitas informasi dan perceived usefulness menunjukkan korelasi signifikan terhadap variabel peranan keberhasilan penerapan software akuntansi. Hasil uji parsialnya sebagai berikut:

Tabel 8. Hasil Uji t

\begin{tabular}{cccc}
\hline \multicolumn{4}{c}{ Coefficients $^{\mathbf{a}}$} \\
\hline & Model & $\mathrm{t}$ & Sig. \\
\hline \multirow{4}{*}{1} & (Constant) & 2,569 & .018 \\
& sisteml & 2.921 & .008 \\
& Informasi & 2,341 & .036 \\
& Usefulness & 2,762 & .028 \\
\hline \multicolumn{2}{c}{ a. Variabel Terikat: software akuntansi } \\
\hline
\end{tabular}

Berdasarkan tabel di atas secara parsial, variabel kualitas sistem, kualitas informasi dan perceived usefulness menunjukkan korelasi signifikan terhadap variabel peranan keberhasilan penerapan software akuntansi.

Kualitas sistem secara signifikan mempengaruhi peranan keberhasilan penerapan software akuntansi. Kebanyakan responden menjawab 
mengenai kualitas sistem yaitu sebesar 36,63 yang menunjukan bahwa mereka setuju jika kualitas sistem berpengaruh positif pada kepuasan mereka dalam menggunakan sistem informasi akuntansi. Karakteristik responden yang sebagian besar dengan usia produktif di bawah 25 tahun, menjadi faktor pendukung karena diusia ini lebih mudah adaptasi untuk menggunakan suatu teknologi yaitu dalam hal ini merupakan sistem akan menjadi lebih mudah untuk dipelajari dan. kualitas sistem yang baik mampu memberi peranan penggunaan software akuntansi Makin baik kualitas sistem yang baik memiliki karakteristik yang dibutuhkan oleh sistem itu sendiri, misalnya dari penelitian yang dilakukan (Almazán dkk., 2017) mengatakan bahwa sistem informasi haruslah tidak mudah error atau gagal, cepat, dan kompatibel. mudah digunakan, ramah pengguna, Andarwati dkk (2019) dan Knauer dkk (2020) yang mengatakan sistem yang berkualitas memiliki karakteristik bekerja tanpa error, memiliki respon waktu yang baik, dan fleksibel.

Kualitas informasi secara signifikan mempengaruhi peranan keberhasilan penerapan software akuntansi.. Responden menjawab mengenai kualitas informasi yaitu sebesar 27,02 bahwa mereka setuju jika kualitas sistem menemukan bahwa kualitas informasi memainkan peran penting dalam meningkatkan manfaat yang dirasakan pengguna dengan memerikan informasi berkualitas tinggi Efiloğlu (2019) mengatakan kualitas informasi memberi dampak yang positif pada kepuasan pengguna karena infromasi yang dihasilkan sesuai dengan apa yang mereka butuhkan.

Perceived usefulness menunjukkan korelasi signifikan terhadap variabel peranan keberhasilan, responden menjawab mengenai kualitas sistem yaitu sebesar 33,61 yang menunjukan bahwa mereka setuju jika kualitas sistem berpengaruh positif pada kepuasan mereka dalam menggunakan sistem informasi akuntansian penerapan software akuntansi,
Andarwati dkk (2020) bahwa pengguna akan merasa puas ketika dengan menggunakan suatu sistem terdapat manfaat yang diperoleh. Selain itu jika dilihat dari karakteristik responden yang sudah bekerja cukup lama yaitu antara mulai dari lima tahun sampai dengan sepuluh tahun ini artinya responden sudah memiliki cukup waktu untuk beradaptasi dan terbiasa dengan menggunakan sistem informasi akuntansi yang ada.

\section{KESIMPULAN DAN SARAN}

Setelah melakukan penelitian dan serangkaian pengujian hipotesis terkait, maka dapat diambil kesimpulan sebagai berikut Variabel kualitas sistem, kualitas informasi dan perceived usefulness menunjukkan korelasi signifikan terhadap variabel peranan keberhasilan penerapan software akuntansi.

Kualitas sistem informasi , kualitas informasi dan perceived usefulness memberi dampak yang positif pada kepuasan pengguna karena infromasi yang dihasilkan sesuai dengan apa yang mereka butuhkan. Sistem yang berkualitas memiliki karakteristik bekerja tanpa error, memiliki respon waktu yang baik, dan fleksibel. Mampu tidaknya seorang pengguna diwaktu mendatang secara subjektif menggunakan teknologi informasi yang secara spesifik dapat meningkatkan kinerja pekerjaan sehingga semua variable memiliki peranan keberhasilan penerapan software akuntansi bagi pegawai bank yang ada di Jakarta Selatan. Faktor-faktor yang mempengaruhi tingkat pengungkapan akibat masih ada faktor-faktor lain yang dapat memberikan peranan keberhasilan penerapan software akuntansi.

Saran bagi entitas dapat
menyediakan atau mengembangkan perangkat lunak atau software yang mampu memaksimalkan sistem informasi sehingga kinerja pengguna sistem lebih baik. Selain itu, keterbatasan dalam penelitian ini hanya menjelaskan sebagian kecil dari peranan software 
akuntansi dam factor lain tidak dimasukkan kedalam penelitian ini karena keterbatasan waktu dan data. Sampel hanya melibatkan Pegawai bank di daerah Jakarta Selatan, sehingga belum mampu menggambarkan secara keseluruhan terkait peranan software akuntansi.

\section{UCAPAN TERIMAKASIH}

Terimakasih kepada kepada UPN Veteran Jakarta terutama Lembaga Penelitian dan Pengabdian Masyarakat yang telah membantu dan mendukung penelitian, dan terimakasih atas bantuan semua responden pegawai bank yang membantu melengkapi data penelitian. Tidak lupa terimakasih kepada tim editor JAMA Politeknik Negeri Batam telah memberikan kesempatan menerima penelitian kami .

\section{DAFTAR PUSTAKA}

Amaliah, E. F., \& Haryanto. (2019). Analisis Faktor-Faktor Yang Memengaruhi Tingkat Pengungkapan Laporan Keuangan Pemerintah Daerah Kabupaten/Kota Di Provinsi Jawa Tengah Tahun 2015-2017. Diponegoro Journal of Accounting, 8(2), 1-13.

Andriani, M., Santi, E., \& Mustika, R. (2019). Faktor-Faktor yang Mempengaruhi Tingkat Pengungkapan Laporan Keuangan Pemerintah Daerah pada Kabupaten / Kota Provinsi Sumatera Barat Tahun Anggaran 2014-2016. Akuntansi Dan Manajemen, 14(1), 1-14. Retrieved from

http://ejournal.pnp.ac.id/index.php/JA $\mathrm{M} /$ article/view/157

Ayu, P. P. (2017). Analisis Faktor-Faktor Pengungkapan Laporan Keuangan Pemeirntah Daerah (Studi Kasus pada Pemerintah Kabupaten dan Kota seJawa Barat). Ekspansi, 9(2), 187-198.

Budiarto, D. S., \& Indarti, L. (2019). Apakah Karakteristik Pemerintah Daerah Berpengaruh Pada
Pengungkapan Laporan Keuangan Pemerintah Daerah? Riset pada Kabupaten di Jawa Tengah. Jurnal Akuntansi Bisnis, 12(1), 19-31. https://doi.org/10.30813/jab.v12i1.15 49

Ghozali, I. (2018). Aplikasi Analisiss Multivariate dengan Program IBM SPSS 25 (Edisi 9). Semarang: Badan Penerbit Universitas Diponegoro.

Hendriyani, R., \& Tahar, A. (2015). Analisis Faktor-Faktor Yang Memengaruhi Tingkat Pengungkapan Laporan Keuangan Pemerintah Provinsi Di Indonesia. Jurnal Bisnis Dan Ekonomi (JBE), 22(1), 25-33.

Lutfia, F. I., Maryono, \& Bagana, B. D. (2018). Determinan Tingkat Pengungkapan Laporan Keuangan Pemerintah Daerah (Studi Kasus Pada Kabupaten/Kota di Provinsi Jawa Tengah Tahun Anggaran 2014-2016) Ferina. Dinamika Akuntansi, Keuangan Dan Perbankan, 7(1), 8295.

https://doi.org/10.1017/CBO9781107 415324.004

Mahmudi. (2019). Analisis Laporan Keuangan Pemerintah Daerah (edisi keen). Yogyakarta: Sekolah Tinggi Ilmu Manajemen YKPN.

Marliani, M., Amin, M., \& Mawardi, M. C. (2018). Pengaruh Karakteristik Pemerintah, Kompeksitas, dan Temuan Audit terhadap Tingkat Pengungkapan Laporan Keuangan Pemerintah Daerah. E-JRA, 07(10).

Najah, U., \& Purwati, A. S. (2019). Analisis Pengaruh Karakteristik PEMDA , Indeks Pembangunan Pengungkapan LKPD. Jurnal Kajian Ekonomi \& Keuangan Daerah, 5(1), 70-88.

Naopal, F., Rahayu, S., \& Yudowati, S. P. (2017). Pengaruh Karakteristik Daerah, Jumlah Penduduk, Temuan Audit, dan Opini Audit Terhadap Pengungkapan Laporan Keuangan Pemerintah Daerah. Assets, 7(1), 5668. 
Nor, W., Hudaya, M., \& Novriyandana, R. (2019). Financial Statements Disclosure on Indonesian Local Government Websites. Asian Journal of Accounting Research, 4(1), 112128. https://doi.org/10.1108/AJAR06-2019-0043

Nosihana, A., \& Yaya, R. (2016). Internet Financial Reporting dan FaktorFaktor yang Mempengaruhinya Pada Pemerintah Kota dan Kabupaten Di Indonesia. Jurnal Dinamika Akuntansi Dan Bisnis, 3(2), 89-104. https://doi.org/10.24815/jdab.v3i2.53 89

Ramdhani, D. (2016b). Analisis FaktorFaktor yang Mempengaruhi Tingkat Pengungkapan Laporan Keuangan Pemerintah Daerah di Provinsi Banten. Jurnal Riset Akuntansi Terpadu, 9(2), 146-161. https://doi.org/10.35448/jrat.v9i2.430 1

Simbolon, H. A. U., \& Kurniawan, C. H. (2015). Pengaruh Karakteristik Pemerintah terhadap Tingkat Pengungkapan Laporan Keuangan Pemerintah Daerah di Indonesia. Accounting Analysis Journal, 30(1), 54-70.

https://doi.org/https://doi.org/10.2400 2/modus.v30il.1587

Soleman, M. T., Pontoh, W., \& Budiarso, N. S. (2019). Pengungkapan Laporan Keuangan Pemerintah Daerah (Studi Kasus Di Kabupaten Kepulauan Talaud). Going Concern : Jurnal Riset Akuntansi, 14(1), 18-21. https://doi.org/10.32400/gc.14.1.2224 9.2019

Sugiyono. (2017). Metode Penelitian Kuantitatif, Kualitatif, dan R\&D. Bandung: Penerbit Alfabeta.

Sujarweni, V. W. (2016). Kupas Tuntas Penelitian Akuntansi dengan SPSS (Mona, ed.). Yogyakarta: Pustaka Baru Press.

Suparno, \& Nanda, R. (2016). Pengaruh Kemandirian Keuangan Daerah,
Diferensiasi Fungsional Dan Spesialisasi Fungsional Terhadap Tingkat Pengungkapan Wajib Laporan Keuangan Pemerintah (2015). Pengaruh Karakteristik Pemerintah terhadap Tingkat Pengungkapan Laporan Keuangan Pemerintah Daerah di Indonesia. Accounting Analysis Journal, 30(1), 54-70.

https://doi.org/https://doi.org/10.2400 2/modus.v30il.1587

Soleman, M. T., Pontoh, W., \& Budiarso, N. S. (2019). Pengungkapan Laporan Keuangan Pemerintah Daerah (Studi Kasus Di Kabupaten Kepulauan Talaud). Going Concern : Jurnal Riset Akuntansi, 14(1), 18-21. https://doi.org/10.32400/gc.14.1.2224 9.2019

Sugiyono. (2017). Metode Penelitian Kuantitatif, Kualitatif, dan R\&D. Bandung: Penerbit Alfabeta.

Sujarweni, V. W. (2016). Kupas Tuntas Penelitian Akuntansi dengan SPSS (Mona, ed.). Yogyakarta: Pustaka Baru Press.

Suparno, \& Nanda, R. (2016). Pengaruh Kemandirian Keuangan Daerah, Diferensiasi Fungsional Dan Spesialisasi Fungsional Terhadap Tingkat Pengungkapan Wajib Laporan Keuangan Pemerintah Daerah. Jurnal Dinamika Akuntansi Dan Bisnis, 3(2), 105-118. https://doi.org/10.24815/jdab.v3i2.53 90 